\title{
Analisis Perubahan Morfologis Pembentukan Ta’rib dan Pembelajaran
}

\author{
Muhammad Afif Amrulloh', Ro'fat Hizmatul Himmah ${ }^{\mathbf{2}}$ \\ ${ }^{1}$ Universitas Islam Negeri Raden Intan Lampung; afif.amrulloh@radenintan.ac.id \\ ${ }^{2}$ Institut Tinggi Agama Islam Darussalam Blokagung Banyuwangi
}

Diterima: 20 September 2017. Disetujui: 30 Oktober 2017. Dipublikasikan: Desember 2017

\begin{abstract}
The birth of a variety of new vocabulary or term in the Arabic language that originated in a foreign language is a form of a modern linguistic phenomenon that emerged at this time. The reality shows that Arabic continues to evolve following the times that certainly gives its own difficulties for speakers of the Arab nation as well as from outside the Arab nation. However, this article will discuss the changes that occur in the morphological process of Arabization. This research used the qualitative research, including the types of research studies library or library research that takes a data source in the library. While the methods used i.e. linguistic analysis methods on morphology to produce conclusions as for the basis for the formation of Arabization. The results of this research show that there is at least some form of absorption process of morphological changes in the words used in the process of Arabization, i.e. ta'rib or morfemis/afiksasi process with the form sirkumfiks, the suffix, and prefix. Some forms of these processes contribute to the understanding of the application of some rules of Arabization to ease the Arab language learners and speakers from outside the Arab nation in learning, understanding and generate new vocabulary needed in communications globally.
\end{abstract}

\begin{abstract}
Abstrak
Penelitian ini akan membahas tentang perubahan morfologis yang terjadi dalam proses arabisasi. Penelitian ini merupakan jenis penelitian kualitatif, termasuk penelitian studi pustaka atau library research yang mengambil sumber data secara kepustakaan. Metode dalam penelitian ini yaitu metode analisis kebahasaan pada morfologi untuk menghasilkan kesimpulan untuk menjadi dasar pembentukan arabisasi. Hasil dari penelitian ini menunjukkan bahwa setidaknya ada beberapa bentuk penyerapan kata dalam proses perubahan morfologis yang digunakan dalam proses ta'rib atau arabisasi, yaitu proses morfemis/afiksasi dengan bentuk sirkumfiks, sufiks dan prefiks. Beberapa bentuk proses tersebut memberikan kontribusi terhadap pemahaman penerapan beberapa kaidah arabisasi sehingga memudahkan para pembelajar bahasa Arab dan penutur dari luar bangsa Arab dalam mempelajari, memahami dan menghasilkan kosa kata baru yang dibutuhkan dalam komunikasi secara global yang lebih luas.
\end{abstract}

Kata Kunci: Arabisasi, Ta'rib, Morfologi

(C) 2017 URPI, FTK UIN Raden Intan Lampung

\section{PENDAHULUAN}

Setiap bahasa yang hidup selalu berkembang mengikuti perkembangan zaman. Seperti halnya Bahasa Arab yang terus berkembang seiring perkembangan masa. Perkembangan ini melahirkan fenomena kebahasaan modern berupa munculnya berbagai kosa kata baru dalam bahasa Arab.

Kosa kata baru yang muncul dalam Bahasa Arab tsangat erat kaitannya dengan peran dan kedudukan bahasa lain di sekitarnya terhadap bahasa Arab. Eksistensi suatu bahasa diindikasikan dengan munculnya kosa kata yang baru 
(Syuhada, 2011). Kondisi ini menciptakan pergaulan atau interaksi antar bahasa sehingga terjadilah pergulatan atau persinggungan bahasa. Selain itu, budaya juga berperan besar dalam menghasilkan kata atau istilah baru. Kontak antara budaya dengan bahasa memang tidak bisa dipisahkan. Keduanya saling berkaitan dan berpengaruh satu sama lain. Dengan demikian, keberadaan budaya memberikan andil terhadap perkembangan suatu bahasa (Astari et al., 2014).

Kemudian perkembangan bahasa Arab berkaitan dengan perkembangan ilmu pengetahuan dan teknologi. Dengan berkembangnya teknologi, maka mengakses informasi sangatlah mudah serta dapat dengan mudah mengenal kemampuan suatu bangsa (Gustini, 2016).

Perkembangan tersebut berdampak pada berkembangnya bahasa Arab. Munculnya berbagai istilah atau kosa kata baru untuk memenuhi kebutuhan penamaan suatu hal yang ditemukan secara ilmiah. Namun, dalam bahasa Arab sendiri tidak semua kosa kata tersedia sehingga membutuhkan adanya kosa kata baru yang mampu mencukupi kebutuhan tersebut.

Oleh karena itu, muncullah berbagai kata atau istilah baru dari bahasa asing ke dalam bahasa Arab atau disebut dengan istilah ta'rib (arabisasi). Seperti yang dilakukan oleh beberapa lembaga bahasa Arab dalam memenuhi kebutuhan kosa kata baru dengan penerjemahan, pembentukan istilah baru, penyerapan dan penyesuaian dengan kaidah-kaidah bahasa Arab (Malik, 2009).

Proses arabisasi melewati beberapa tahap sebelum kosa kata asing menjadi kosa kata baru dalam bahasa Arab. Terjadi berbagai perubahan, baik pada aspek bunyi atau fonologi maupun pada aspek morfologi atau bentuk kata. Adapun yang menjadi pembahasan dalam tulisan ini yaitu terkait munculnya kosa kata baru atau arabisasi pada salah satu tataran linguistik yaitu morfologi. Dengan demikian akan dapat diketahui kaidah morfologis yang akan digunakan dalam membentuk ta'rib tersebut.

Dalam beberapa riset yang pernah dilakukan, seperti yang dilakukan oleh (Hadi, 2002) bahwa terdapat tiga cara dalam pembentukan ta'rib yaitu dengan penyerapan, penerjemahan dan pembentukan istilah baru. Pola penyerapan seringkali digunakan oleh para leksikograf bahasa Arab dalam menghasilkan kata atau istilah baru yang berasal dari bahasa asing. Sedangkan penerjemahan serta pembentukan istilah baru lebih banyak dilakukan oleh lembaga-lembaga bahasa (Hadi, 2002).

Darheni (2009) menyatakan bahwa penyerapan tersebut ditinjau dari segi morfologis dapat dibentuk melalui tiga cara, yaitu afiksasi, reduplikasi dan abreviasi. Afiksasi dalam bidang otomotif dengan menggunakan perfiks atau awalan berupa me-, ber-, di-, ter-, dan pe-. Kemudian bisa pula dengan reduplikasi atau pengulangan (Darheni, 2009). Contoh salah satu hasil penelitian arabisasi atau ta'rib dalam bahasa Arab dengan pendekatan morfologis yang dilakukan oleh Syamsul Hadi, bahwa pembentukan ta'rib salah satunya yaitu pembentukan berdasarkan aturan morfologi yang terdapat dalam bahasa Arab. Pembentukan ini dilakukan setelah transkripsi dan penyesuaian lafal dengan kelaziman dalam bahasa Arab. Misalnya kata dari bahasa Inggris pathologist, yang kemudian diserap oleh bahasa Arab serta disesuaikan dengan pelafalan yang umum dalam bahasa Arab dan sesuai dengan aturan morfologi bahasa Arab sehingga menjadi pathologist (الباتولوجيا). Dalam bahasa Arab, penambahan ya nisbah tersebut dengan tujuan untuk menunjukkan kata dalam bahasa Inggris yang berakhiran ist dan er (Hadi, 1995).

Dalam kajian ta'rib ini, pengaraban terhadap kata asing ke dalam bahasa Arab 
melibatkan beberapa proses, yaitu proses fonologis dan yang kedua proses morfologis berdasarkan aturan yang digunakan dalam bahasa Arab. Dengan berbagai penambahan yang ada, maka perlu dipahami tambahan-tambahan yang diperlukan dalam pembentukan kata atau istilah baru dalam bahasa Arab.

Dengan demikian, tulisan ini akan membahas tentang proses pembentukan kata atau istilah baru (arabisasi) pada aspek morfologis dan pembelajarannya. Tataran linguistik tersebut penting terhadap pembelajaran dan pemahaman dalam proses pembentukan ta'rib secara komprehensif.

\section{LANDASAN TEORI \\ Istilah Ta'rib (Arabisasi)}

Ta'rib adalah bentuk masdar dari

kata kerja عرب yang berarti penerjemahan

ke dalam bahasa Arab. Makna ta'rib atau arabisasi menurut Syamsul Hadi bahwa merupakan penyerapan unsur-unsur asing, baik berapa kata ataupun istilah. Unsur asing berupa kata atau istilah masuk ke dalam bahasa Arab dengan mengalami berbagai penyesuaian sehingga menjadi kosa kata yang baru dalam bahasa Arab (Hadi, 2002).

Menurut Ismail Ubaidillah, ta'rib merupakan kata yang berasal dari bahasa asing yang diambil ke dalam bahasa Arab dengan melakukan berbagai perubahan, baik dengan pengurangan huruf, penambahan huruf ataupun penggantian huruf sehingga menjadi bahasa Arab. Arabisasi ini untuk menjawab kebutuhan terhadap penamaan sesuatu hal yang belum memiliki nama dalam bahasa Arab (Ubaidillah, 2013).

Pada pengertian tersebut, dapat diketahui setidaknya aspek perubahan morfologi yang termasuk dalam proses arabisasi yaitu penambahan huruf. Penggantian huruf terkait aspek fonologi atau bunyi yang disesuaikan dengan lazimnya dalam bahasa Arab.
Pembentukkan kata atau istilah baru dalam bahasa Arab dari bahasa asing yang dikenal dengan arabisasi ini memiliki beberapa aturan atau kaidah, yaitu sebagai berikut:

1. Kaidah dasar, kaidah ini mencakup perubahan dasar pada suara atau fonemik dan pada tataran morfologis.

2. Keserasian dalam aspek morfologis bahasa Arab.

Pola atau kaidah dasar tersebut, digunakan oleh ulama bahasa modern dalam proses arabisasi yang sesuai dengan aturan yang berlaku dalam bahasa Arab. Hal ini mencakup kedekatan perubahan aspek suara dan keteraturan susunan hurufnya. Dengan menggunakan pola wazan saraf sebagai panduan dasar dalam merubah huruf pada kata asing sebagai huruf asli (Ubaidillah, 2013).

Dalam kitab Al-Muzhir fi 'ulumi alLughah wa Anwa'iha karya Abdurahman Jalaluddin Al-Suyuti yang dikutip oleh Muhammad Afif Amrulloh bahwa dalam pembentukan ta'rib bisa mengandung tambahan ataupun pengurangan huruf. Tambahan atau pengurangan tersebut terjadi pada awal kata dasar ataupun pada akhir kata dasar secara bersamaan. Tambahan ini bisa dengan dua huruf ataupun lebih, sementara itu pengurangannya disesuaikan dengan lisan atau kaidah orang Arab (Amrullah, 2015).

\section{Perubahan Morfologis}

Morfologi mempelajari dan menganalisis struktur, bentuk dan klasifikasi kata. Ia merupakan salah satu kajian dalam tataran linguistik yang membahas tentang pembentukan kata. Kata yang disusun dari gabungan huruf dan kemudian selanjutnya menjadi beberapa kata sehingga terbentuklah kalimat. Pembahasan kata dalam morfologi tentunya terkait kata yang memiliki makna dan digunakan dalam pembentukan kalimat atau gramatikal. 
Seperti halnya dalam linguistik bahasa Arab, kajian morfologi dikenal dengan nama ilmu sharaf/tasrif. Ilmu yang mengupas seputar seluk beluk kata atau proses terbentuknya suatu kata. Perubahan suatu bentuk kata (asal) menjadi bentuk yang bermacam-macam untuk mendapatkan makna yang berbeda atau makna yang baru.

Dalam pembentukan kata, ada dua sifat yang dimiliki oleh kata yaitu inflektif dan derivatif. Oleh karenanya, dalam bahasa Arab keduanya memegang peranan yang penting terhadap proses pembentukan kata (Ridwan dan Hidayati, 2015). Inflektif maksudnya adalah bahwa penyesuaian bentuk kata terhadap kaidah gramatikal yang berlaku pada sistem bahasa tertentu. Penyesuaian ini bisa menggunakan berbagai bentuk, baik denga afiks, prefiks, infiks dan sufiks. Bisa pula penyesuian dalam hal bentuk kata verba atau nomina. Verba yang di dalamnya tentunya ada tense berkaitan dengan waktu. Kalau dalam bahasa Arab dijumpai dengan nama madhi dan mudhari'. Contoh dari jenis sifat kata inflektif ini misalnya dalam bahasa Indonesia dengan bentuk leksikal sama, ada membaca, dibaca, terbaca (Chaer, 1994).

Seperti yang sudah dijelaskan sebelumnya bahwa dalam pembahasan linguistik umum, morfologi modern membentuk kata dengan melibatkan proses morfologis, yang disebut dengan derivasi dan infleksi. Proses derivasi (isytiqaq al-Asma), merubah kelas kata dari unsur leksikal tertentu menjadi unsur leksikal yang lain. Sedangkan infleksi (tasrif al-Fi'li) tidak merubah kelas kata, tetap sebagai unsur leksikal yang sama. Ada enam bentuk proses morfemis, yaitu (Lutfi, 2012):

1. Prefiks,

Merupakan afiks yang ditambahkan pada awal kata dasar. Misalnya dari kata شغل menjadi kata أشغل.
2. Sufiks

Merupakan afiks yang ditambahkan di akhir kata dasar. Misalnya dari kata بشر menjadi kata بشري.

3. Infiks

Merupakan afiks yang ditambahkan di tengah kata dasar. Misalnya dari kata قتل menjadi kata قاتل.

4. Sirkumfiks

Merupakan afiks yang bisa dipisahpisah, ditambahkan pada kata dasar secara serentak. Misalnya dari kata جلس menjadi kata جلسون.

5. Konfiks

Merupakan afiks yang tidak bisa dipisah-pisah, ditambahkan pada kata dasar secara serentak. Misalnya dari kata ختخرج menjadi kata استخرج.

6. Transfiks

Merupakan penambahan dengan unsure vokal. Dikenal pula dengan nama modifikasi internal. Misalnya dari kata فتح menjadi kata فتح.

Proses morfemis tersebut di atas disebut pula dengan afiksasi, yaitu penambahan huruf atau bunyi, baik berupa perfiks (al-sawabiq), infiks (aldawakhil) ataupun sufiks (al-lawahiq) (Mufrodi \& Mufrodi, 2015). Adapun afiksasi yang menjadi pembahasan dalam tulisan ini yaitu afiks yang menunjukkan pembentukan kata baru dalam ta'rib.

Ada beberapa ketentuan dalam perubahan morfologis dari bahasa asing yang disesuaikan dengan aturan yang berlaku dalam kaidah bahasa Arab, yaitu (Malik, 2009):

\section{Penyerapan Kata atau Istilah}

Penyerapan ini dilakukan dengan perubahan secara fonologis yang sesuai dengan ketentuan atau pelafalan dalam bahasa Arab dan kemudian disesuaikan 
pada aspek morfologis yang sesuai dengan aturan dalam bahasa Arab:

1. Misalnya suatu kata yang berbahasa Inggris dengan akhiran ist dan er, maka diberikan penambahan pada akhir kata dalam bahasa Arab dengan menggunakan ya' nisbah.

2. Demikian pula untuk kata sifat dalam bahasa Inggris yang berakhiran an, $i c$, al, ive dengan menambahkan pada akhir kata dalam bahasa Arab menggunakan ya' nisbah.

Perubahan fonologis pada ta'rib yang sesuai dengan pelafalan bahasa Arab dalam membentuk kata baru dianggap sebagai kata dasar. Setelah itu dilakukan penyesuaian dalam aspek morfologis maupun sintaksis sesuai dengan kaidah dalam bahasa Arab. Proses morfologis sebagai ajektif (Hadi, 2002).

Cara tersebut di atas seperti yang disampaikan oleh Syamsul Hadi dalam tulisannya yang berjudul Kata dan Istilah Asing dalam Bahasa Arab, bahwa setelah dilakukan penyerapan kata sesuai dengan kelaziman pelafalan dalam bahasa Arab, kemudin disesuaikan pula dengan kaidah morfologi yang berlaku pada bahasa Arab. Ia mencontohkan kata-kata yang dalam bahasa Inggris berakhiran ist dan er maka pembentukan kata baru dalam bahasa Arab dengan menambahkan $y a$ ' nisbah.

Misalnya:

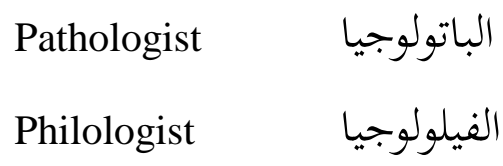

Phenomenologist الفينومينولوجيا

Sedangkan untuk ajektiva yang berakhiran -an, -ic, -al, -ive juga diberikan tambahan berupa ya' nisbah.

أنيمي Misalnya kata anemic menjadi (Hadi, 1995).

\section{Penerjemahan}

Dalam penerjemahan dengan menambahkan iyyah pada akhir kata untuk kata asing (bahasa Inggris) yang menggunakan akhiran ism dan ics. Selain itu dapat pula menggunakan perfiks atau sufiks dari suatu kata yang kemudian digabungkan dengan kata yang lain sehingga menjadi kosa kata atau istilah baru dalam bahasa Arab.

\section{Pembentukan Istilah Baru}

Pembentukan istilah baru ini dilakukan dengan menggunakan perubahan atau penyesuian wazan dalam ilmu saraf. Seperti wazan yang digunakan untuk menunjukkan tempat, alat, waktu dan sebagainya.

\section{METODE PENELITIAN}

Penelitian ini bertujuan untuk mengetahui proses perubahan morfologis arabisasi pada Majalah Majma' al-Lugah al-'Arabiyyah al-Malaky juz yang ke-3. Penelitian dilakukan dengan menggunakan pendekatan kebahasaan yaitu morfologi. Maksudnya pendekatan morfologi bahwa pendekatan kebahasaan yang melihat bahasa berdasarkan pada aspek perubahan kata guna menghasilkan kesimpulan sebagai dasar perubahan morfologis pada arabisasi.

Penelitian ini dilaksanakan terhadap kata arabisasi pada Majalah Majma' alLugah al-'Arabiyyah al-Malaky juz ke-3. Pemilihan tersebut didasarkan pada peran majalah ini yang membukukan hasil dari pembukuan terhadap istilah-istilah atau kata-kata baru yang muncul dalam bahasa Arab dan kemudian dibukukan oleh Lembaga bahasa Arab Mesir tersebut.

Pengumpulan data dilakukan melalui teknik dokumentasi, yaitu berdasarkan pustaka, baik berupa buku, jurnal maupun hasil penelitian lain yang terkait dengan kajian dalam pembahasan ini. Penelitian tentang perubaan morfologis ta'rib ini dilakukan oleh peneliti dengan menggunakan jenis 
penelitian studi pustaka atau library research yang mengambil sumber data secara kepustakaan.

Jenis penelitian ini yaitu penelitian kualitatif dengan memaparkan data-data yang kemudian dianalisis secara sistematis. Kata-kata atau istilah-istilah baru dalam bahasa Arab (ta'rib) pada Majalah Majma' al-Lugah al- 'Arabiyyah al-Malaky juz ke-3 yang menjadi objek material penelitian ini dan juga sekaligus sebagai sumber data primer. Sedangkan objek formal penelitian ini yaitu kajian tentang perubahan morfologis.

Teknik analisis data dengan menggunakan penelitian deskriptif. Penelitian yang memaparkan berbagai data atau permasalahan dan kemudian dianalisis dengan menggunakan pendekatan morfologi pada setiap kata atau istilah baru dalam bahasa Arab.

\section{HASIL DAN PEMBAHASAN}

Setelah melewati proses fonologis, pembentukan kata baru dalam ta'rib selanjutnya memasuki tahap proses perubahan morfologis. Perubahan morfologis atau proses morfemis/afiksasi yang pertama dilakukan dengan bentuk sirkumfiks, afiks yang bisa dipisah-pisah, ditambahkan pada kata dasar secara serentak atau bersamaan. Bentuk afiksasai ini merupakan bentuk gabungan antara perfiks dan sufiks, misalnya:

Tabel 1. Perubahan morfologis atau afiksasi

\begin{tabular}{|c|c|}
\hline Istilah Asing & Ta'rib \\
\hline Franciscans & الفرنسسكيون \\
\hline Dominicans & الدمنكيون \\
\hline
\end{tabular}

Proses arabisasi pada kedua kata tersebut di atas, secara morfologis melewati beberapa tahap. Di dalamnya terjadi proses derivasi atau isytiqaq alAsma, yaitu perubahan kelas kata dari unsur leksikal tertentu menjadi unsur leksikal lain. Dari bentuk tunggal atau mufrad menjadi bentuk plural atau jama'.

Bentuk jama' kata benda tersebut mengacu pada tambahan akhir huruf pada kata Franciscans dan Dominicans yaitu berupa huruf "s". Huruf tersebut dalam bahasa Inggris digunakan untuk menunjukkan suatu benda yang bermakna banyak atau plural. Sedangkan dalam bahasa Arab untuk menunjukkan makna banyak atau jama' terhadap suatu benda atau orang maka digunakan tambahan

ketika rafa' dan ين ketika nasab atau jar dalam jenis jama' mudzakar salim atau jama' yang beraturan.

Beraturan maksudnya perubahannya terjadi secara teratur dengan menggunakan tambahan huruf-huruf tersebut. Kedua kata tersebut dimaknai sebagai kata yang bersifat 'laki-laki' atau mudzakar sehingga menggunakan tambahan ون atau di akhir katanya. Namun jika kedua kata tersebut dimaknai lain, yaitu menenjukkan 'perempuan' atau muanats, maka tentunya menggunakan tambahan berupa alif dan ta, seperti kata al-Muslimat.

Tambahan tersebut dalam kajian linguistik dikenal dengan nama sufiks, yaitu tambahan afiks pada akhir kata dasar, berupa g. Sehingga dengan demikian terbentuklah kata فرنسسكيون dan دمنكيون yang menunjukkan makna banyak (orang) dengan kaidah sebagai jama' mudzakar salim yang rofa'.

Kemudian proses morfologis selanjutnya yaitu dengan membubuhkan tambahan dua huruf pada awal kata dasar yang dikenal dengan nama sufiks. Tambahan tersebut berupa llau alif lam. 
Hal ini didasarkan pada makna yang dikehendaki dalam menghasilkan ta'rib tersebut yaitu menunjukkan makna orang atau kata benda yang jelas (ma'rifah) dan diketahui secara nyata adanya. Dengan demikian, maka terbentuklah kosa kata baru dalam ta'rib untuk kata "Franciscans" dan "Dominicans" dari

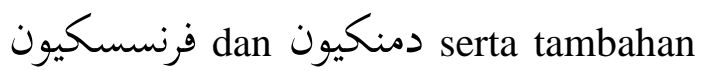

sufiks dua huruf berupa latau alif lam pada awal kata dasar sehingga menjadi الدمنكيون dan الفرنسسكيون.

Proses afiksasi tersebut melibatkan tambahan huruf pada dua posisi, yaitu posisi depan kata dasar dan posisi belakang kata dasar yang dihadirkan secara bersamaan. Akan tetapi, dapat juga kedua posisi tersebut hadir secara terpisah atau tidak serentak. Kondisi afiksasi seperti ini dikenal dengan bentuk sirkumfiks.

Contoh berikutnya yang masih dalam bentuk yang sama (bentuk sirkumfiks) dari hasil arabisasi ini yaitu:

Tabel 2. Bentuk sirkumfiks dari hasil arabisasi

\begin{tabular}{|c|c|}
\hline Istilah Asing & Ta'rib \\
\hline Magnetic & المغنطيسي \\
\hline Histoplasmosis & الهستوبلازمية \\
\hline Hydrogenation & الهدرجة \\
\hline Alkylation & الأكالة - ل مالة \\
\hline
\end{tabular}

Proses arabisasi pada kedua kata tersebut di atas, secara morfologis melewati beberapa tahap. Di dalamnya terjadi proses derivasi atau isytiqaq alAsma, yaitu perubahan kelas kata dari unsur leksikal tertentu menjadi unsur leksikal lain. Dari suatu kata benda tertentu menjadi bentuk kata benda yang lain yang mengandung makna ajektiva atau kata sifat dalam bahasa Inggris.

Bentuk kata sifat tersebut mengacu pada tambahan akhir huruf pada kata Magnetic dan Histoplasmosis yaitu untuk menunjukkan sifat dan proses. Dalam bahasa Inggris, kata yang berakhiran an, $i c$, al, ive dengan menambahkan pada akhir kata dalam bahasa Arab menggunakan ya' nisbah dan iyyah.

Tambahan tersebut dalam kajian linguistik dikenal dengan nama sufiks, yaitu tambahan afiks pada akhir kata dasar, berupa ya nisbah dan iyyah. Sehingga dengan demikian terbentuklah kata هستوبلازمية dan dang menunjukkan makna ajektiva atau sifat.

Kemudian proses morfologis selanjutnya yaitu dengan membubuhkan tambahan dua huruf pada awal kata dasar yang dikenal dengan nama sufiks.

Tambahan tersebut berupa llau alif lam. Hal ini didasarkan pada makna yang dikehendaki dalam menghasilkan ta'rib tersebut yaitu menunjukkan makna kata benda yang jelas ( $m a$ 'rifah) dan diketahui secara nyata adanya. Dengan demikian, maka terbentuklah kosa kata baru dalam ta'rib untuk kata Magnetic dan Histoplasmosis dari مغنطيسي dan هستوبلازمية dengan tambahan sufiks dua huruf berupa latau alif lam pada awal kata dasar sehingga menjadi المغنطيسي dan الفستوبالازمية.

Sama seperti kata hasil arabisasi sebelumnya yang memiliki proses afiksasi dengan melibatkan tambahan huruf pada dua posisi, yaitu posisi depan kata dasar dan posisi belakang kata dasar yang dihadirkan secara bersamaan. Dapat pula kedua posisi tersebut hadir secara terpisah atau tidak serentak. Kondisi afiksasi seperti ini dikenal dengan bentuk sirkumfiks.

Perubahan morfologis atau proses morfemis/afiksasi yang kedua dilakukan 
dengan bentuk sufiks, yaitu afiks yang ditambahkan di akhir kata dasar.

Tabel 3. Afiksasi bentuk sufiks.

\begin{tabular}{|l|r|}
\hline Istilah Asing & \multicolumn{2}{|c|}{ Ta'rib } \\
\hline Clericalism & هلنيروسية \\
\hline Hellenistic & \\
\hline
\end{tabular}

Proses arabisasi pada kedua kata tersebut di atas, secara morfologis melewati beberapa tahap. Di dalamnya terjadi proses derivasi atau isytiqaq alAsma, yaitu perubahan kelas kata dari unsur leksikal tertentu menjadi unsur leksikal lain. Dari suatu kata benda tertentu menjadi bentuk kata benda yang lain yang mengandung makna ajektiva atau kata sifat dalam bahasa Inggris.

Bentuk kata sifat tersebut mengacu pada tambahan akhir kata -ic pada kata Hellenisticyaitu untuk menunjukkan sifat atau ajektiva. Dalam bahasa Inggris, ajektiva yang berakhiran an, ic, al, ive dalam bahasa Arab dengan menambahkan pada akhir kata berupaya' nisbah. Sehingga dalam ta'rib, setelah melewati proses penyesuaian bunyi, kemudian selanjutnya masuk pada tahap afiksasi sesuai dengan kaidah dalam bahasa Arab maka terbentuklah kata هلنستي dengan tambahan ya nisbah di akhir kata.

Demikian pula untuk bentuk kata sifat mengacu pada tambahan akhir huruf -ism pada kata Clericalism yaitu untuk menunjukkan sifat atau ajektiva. Dalam bahasa Inggris, ajektiva yang berakhiran ism, -ics dalam bahasa Arab dengan menambahkan pada akhir kata berupaiyyah. Sehingga dalam ta'rib, setelah melewati proses penyesuaian bunyi, kemudian selanjutnya masuk pada tahap afiksasi sesuai dengan kaidah dalam bahasa Arab maka terbentuklah kata dengan tambahan iyyah di akhir kata.

Tambahan akhir kata pada kedua kata tersebut di atas, dalam kajian linguistik dikenal dengan nama sufiks, yaitu tambahan afiks pada akhir kata dasar, berupa ya nisbah dan iyyah. Sehingga dengan demikian terbentuklah kata كليروسية dan yang menunjukkan makna ajektiva atau sifat.

Perubahan morfologis atau proses morfemis/afiksasi yang ketiga dilakukan dengan bentuk prefiks, yaitu afiks yang ditambahkan pada awal kata dasar.

Setelah melewati proses fonologis, pembentukan kata baru dalam ta'rib selanjutnya memasuki tahap proses perubahan morfologis. Berikut beberapa kata hasil arabisasi yang dilakukan dengan proses perubahan morfologis atau afiksasi bentuk prefiks sebagai berikut:

Tabel 4. Afiksasi bentuk prefix

\begin{tabular}{|c|c|}
\hline Istilah Asing & Ta'rib \\
\hline Alamanni & الألمان \\
\hline Franks & الفرنجة \\
\hline Armada & الأرمادا \\
\hline Vandal & الوندل \\
\hline Huns & الهون \\
\hline Magnet & المغنطيس \\
\hline Delta & الدلتا الديا \\
\hline Dinamo & الدينمو ل \\
\hline Dinamometer & الدينموميتر \\
\hline Griffin & الغرفين \\
\hline Furfural & الفرفرال \\
\hline Ankylostoma & الانكلستوما \\
\hline Baignoire & البنوار \\
\hline Loge & اللوج \\
\hline Hotel & الأوبيل \\
\hline Salon & الصالونات \\
\hline
\end{tabular}

Proses arabisasi pada kata-kata tersebut di atas, secara morfologis melewati beberapa tahap. Di dalamnya terjadi proses derivasi atau isytiqaq alAsma, yaitu perubahan kelas kata dari unsur leksikal tertentu menjadi unsur leksikal lain. Dari suatu kata benda belum jelas atau nakirah menjadi bentuk kata benda yang lain yang mengandung makna jelas atau ma'rifah. 
Kemudian proses morfologis dipenuhi yaitu dengan membubuhkan tambahan dua huruf pada awal kata dasar yang dikenal dengan nama sufiks.

Tambahan tersebut berupa llau alif lam. Hal ini didasarkan pada makna yang dikehendaki dalam menghasilkan ta'rib tersebut yaitu menunjukkan makna kata benda yang jelas ( $m a$ 'rifah) dan diketahui secara nyata adanya. Dengan demikian, maka terbentuklah kosa kata baru dalam ta'rib untuk kata seperti pada tabel di atas dengan tambahan sufiks dua huruf berupa

I atau alif lam pada awal kata dasar.

\section{PENUTUP}

Arabisasi atau ta'rib merupakan produk dari perkembangan bahasa Arab. Bahasa Arab sebagai bahasa dunia mengalami perkembangan terus menerus mengikuti perkembangan zaman. Terlebih jangkauannya yang mendunia sehingga semakin tidak mampu menghindar dari sifat bahasa yang terus berkembang secara alami. Oleh karena itu, fenomena ini sebagai bentuk pemenuhan kebutuhan kosa kata baru terhadap penamaan yang belum tersedia di dalam bahasa Arab.

Dalam pembentukan ta'rib melibatkan dua proses, yaitu proses perubahan fonologis dan proses perubahan morfologis. Perubahan morfologis atau proses morfemis/afiksasi dilakukan setelah melewati proses fonologis, yaitu perubahan fonologis yang sesuai dengan pelafalan bahasa Arab.

Kajian dalam tulisan ini menitikberatkan pada aspek perubahan morfologis yang merupakan kajian pembelajaran ilmu saraf. Berdasarkan hasil penelitian, ditemukan tiga bentuk afiksasi atau proses morfemis yang digunakan, yaitubentuk sirkumfiks, sufiks dan prefiks. Bentuk sirkumfiks yaitu proses afiksasi yang bisa dipisah-pisah, ditambahkan pada kata dasar secara serentak. Sedangkan sufiks merupakanafiks yang ditambahkan di akhir kata dasar. Prefiks, afiks yang ditambahkan pada awal kata dasar.

Beberapa bentuk perubahan morfologis tersebut di atas dapat dijadikan sebagai gambaran terkait pola yang digunakan dalam pembelajaran dan pembentukan kosa kata baru sebagai hasil arabisasi atau ta'rib. Hal ini tentunya akan membantu mempermudah pembelajaran dan pemahaman dalam mendapatkan kosa kata baru yang dibutuhkan pada kegiatan komunikasi global yang lebih luas. Dengan demikian, kosa kata yang belum tersedia mampu dimunculkan untuk memenuhi ketersediaan kosa kata seiring dengan perkembangan bahasa yang dialami oleh bahasa Arab di antara pergaulan bahasabahasa lain di dunia.

\section{DAFTAR PUSTAKA}

Amrullah, M. A. (2015). الزغة العربية

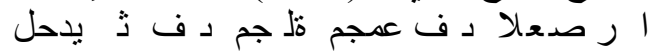

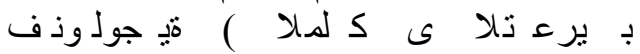

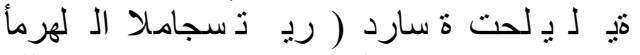

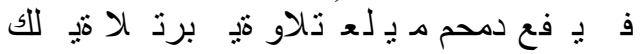

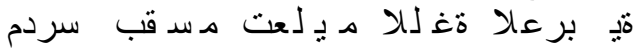

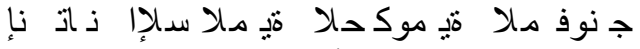

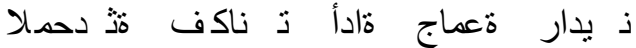

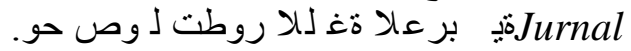
Al Bayan: Jurnal Jurusan Pendidikan Bahasa Arab, 7(1).

Astari, R., Hadi, S., Poedjosoedarmo, S., \& Suhandano. (2014). Pengaruh Budaya terhadap Istilah Sains dan Teknologi dalam Bahasa Arab. Adabiyyat, 13(2), 253-276.

Chaer, A. (1994). Linguistik Umum. Jakarta: Rineka Cipta.

Darheni, N. (2009). Penyerapan Leksikon Asing dalam Bidang Otomotif Kedalam Bahasa Indonesia: Sosioteknologi, 17(8), 646-666.

Gustini, N. (2016). Bimbingan dan Konseling Melalui Pengembangan Akhlak Mulia Siswa Berbasis Pemikiran AL-Ghazali. Tadris: Jurnal Keguruan Dan Ilmu 
Tarbiyah, 1(1), 1-14.

Hadi, S. (1995). Kata dan istilah Asing dalam Bahasa Arab. Humaniora, (1), 113-120.

Hadi, S. (2002). Berbagai Ketentuan Baru dalam Ta , Rib: Pembahasan Seputar Perkembangan Mutakhir dalam Bahasa Arab Seri V. Humaniora, XIV(1), 77-85.

Lutfi, K. M. (2012). Afiksasi sebagai Upaya Integrasi antara Teori Tasrif Al-Af'al Klasik dengan Morfologi Modern. JURNAL ISLAMIC REVIEW, 1(1), 17-47.

Malik, A. (2009). Arabisasi (Ta'rib) dalam Bahasa Arab (Tinjauan Deskriptif-Historis). Adabiyyat, 8(2), 261-276.

Mufrodi, M., \& Mufrodi. (2015). Fonologi dan morfologi bahasa Arab 'amiyah Mesir. Arabiyat: Jurnal Pendidikan Bahasa Arab Dan Kebahasaaraban, 2(2), 192-215. https://doi.org/10.15408/a.v2i2.2184

Muhammad Ridwan dan Triyanti Nurul Hidayati. (2015). Verba Triliteral Bahasa Arab: Tinjauan dari Prepektif Morfologi Derivasi Dan Infleksi. Bahasa \& Sastra, 15(1).

Syuhada, A. (2011). Sistem Morfologi Nomina Variabel (Ism Mutasharrif) Bahasa Arab. At-Ta'dib, 6(2), 269289. https://doi.org/10.21111/ATTADIB.V6I2.560

Ubaidillah, I. (2013). Kata Serapan Bahasa Asing dalam Al-Qur'an dalam Pemikiran At-thobari. Jurnal At-Ta'dib, 8(1), 119-132. 